Contacts

Publisher: Fabien Savenay

Editor: Paul Smaglik

Sales Director: Ben Crowe

European Head Office

London

The Macmillan Building

4 Crinan Street

London N1 9XW, UK

Tel +44 (0) 2078434961

Fax +44 (0) 2078434996

e-mail: naturejobs@nature.com

Group European Manager: Leonie Welss (4954)

European Manager:

Nevin Bayoumi (4978)

UK/ RoW/ Ireland:

Matt Powell (4953), Ben Corp (4974),

Andy Douglas (4975)

Holland/ Italy: Nevin Bayoumi (4978)

Scandinavia: Sille Opstrup (4994)

Spain/ Portugal: Leonie Welss

(4954)

Production Manager: Billie Franklin

To send films and materials use

London address above.

Tel +44 (0) 2078434814

Fax +44 (0) 2078434996

e-mail: naturejobs@nature.com

International

Advertising Coordinator:

Laura Pearson (4977)

Naturejobs web development:

Tom Hancock

Naturejobs online production:

Benlund

European Satellite Offices

France/ Belgium:

Christine Niox-Chateau

Tel + 33 (0) 143201651

$\mathrm{Fax}+33(0) 143205152$

e-mail: c.nioxchateau@nature.com

Germany/ Austria/ Switzerland:

Patrick Phelan/Kate Tumer

$\mathrm{Tel}+4989549057$ 11/-2

Fax +498954905720

e-mails: p.phelan@nature.com

k.tumer@nature.com

US Head Office, New York

345 Park Avenue South,

10th Floor, New York, NY 10010-1707

Tel +1 8009897718

$\mathrm{Fax}+18009897103$

e-mail: naturejobs@natureny.com

US Sales Director: Ben Crowe

US Sales Manager: Peyton Maso

US Advertising Coordinator

Ashly de Leon

Japan Head Office, Tokyo

MG Ichigaya Building (5F)

19-1 Haraikatamachi,

Shinjuku-ku,

Tokyo 162-0841

Tel +81 332678751

Fax +81332678746

e-mail: k.cowan@naturejpn.com

Japan Manager: Kate Cowan

\title{
natuirejobs
}

\section{Cutting into the triangle}

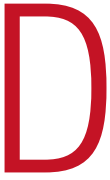

uring a visit to North Carolina's Research Triangle - an area delineated by Duke University, the University of North Carolina at Chapel Hill, and the State University of North Carolina - conversations I'd had with professors and biotech employees gave me a specific impression. It seemed that scientists were being drawn to the area not just by the research activity, but also by the lower cost of living and easier commutes compared with other research-rich areas such as California and the 'Northeast corridor' (see pages 4-5). But I needed further evidence — perhaps a random sample.

Fate - and my clumsiness - conspired to give me just that. After leaving an interview at Duke University, I somehow managed to slice open a finger on a paper-towel dispenser. Fortunately, I was near to Duke's medical centre and, even more fortunately, a nurse there, sensing my perhaps misplaced urgency to make my next appointment, found a free physician. Paul Kuo, head of transplant surgery at the medical centre, even had the patience to tolerate a running tape recorder and my incessant questioning as he looked after the cut (I turned the machine off when he actually started stitching).

Kuo, it turns out, was recruited from Georgetown University in Washington DC about a year ago. He was attracted by the area's research climate - his next-door neighbour is involved in a biotech start-up — and Kuo no longer needs to justify time away from surgery, as Duke's hospital is not operated under a Health Maintenance Organization in the way that Georgetown's now is.

But Kuo notes that the intangibles are equally attractive. In North Carolina he has a larger house with more land than he could have afforded in Washington. And he doesn't have to load his childrens' bicycles into the car and drive them to a safe place to ride. "Life is so much easier here," he says.

\section{Paul Smaglik}

Naturejobs editor
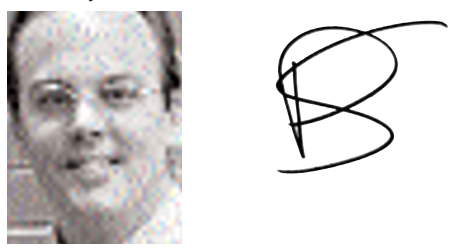

FOCUS

SPOTLIGHT

RECRUITMENT

SCIENTIFIC ANNOUNCEMENTS

SCIENTIFIC EVENTS areer centre

Information on the scientific job market 